\title{
Tobaccopreneur:
}

\section{Determining of Selling Price with Intermediaries}

\author{
Aminatus Zakhra \\ Economics and Accounting \\ University of Islam Madura \\ Pamekasan, Indonesia
}

\author{
Amaliyah* \\ Economics and Business Department \\ University of Trilogi \\ Jakarta, Indonesia \\ *amaliyah@trilogi.ac.id
}

\begin{abstract}
The main agricultural product of Madura Island is tobacco. Tobacco from Madura Island is different from other regions because of its distinctive aromatic odor so prices are different. Madura tobacco productivity is determined based on TPI (Tobacco Planting Index) which is determined from total production and leaf quality. The purpose of this study is to get a detailed description of how Madura tobacco farmers determine the selling price and constraints owned by farmers in determining the selling price of tobacco which can then be used as a recommendation in government policy to stabilize tobacco prices in the market. This type of research is a qualitative study by distributing interviews with farmers. The results obtained from this study are the determination of the price of tobacco based on the decision of a middleman where farmers do not have a good bargain. Farmers only count from tobacco seeds and tobacco fertilizer without calculating the desired profit margins. Therefore, there is a need for assistance and directed technical guidance from the government that starts from the correct tobacco planting to produce quality crops. Furthermore, local government policy is needed to create a strategy in determining competitive harvest prices so farmers can increase profits that have a positive impact on the welfare of farmers, and oversee the existing tobacco mafia.
\end{abstract}

\section{Keywords—tobaccopreneur, selling price, government policy}

\section{INTRODUCTION}

Madura is a lot of positive things found in Madurese with the stigma of being a hard worker, a great trader and maintaining family honor so that it will happen carok if family honor is downplayed. In addition to individuals, the work of many Madurese, such as carvings, food, and batik. Madura Batik has unique characteristics compared to other regions of batik. Batik is the work of the Indonesian people who have been patented and recorded by UNESCO [1]. There is one of Madura's superior agricultural products and has become identical which is often known as Madura tobacco. A tobacco farmer from Pamekasan explained that Madura tobacco is very different from other regions because of its distinctive aromatic odor, so the price is different. Tobacco farmers are mostly in the Pamekasan district [2].
Madura tobacco is a semi-aromatic tobacco so quality determines price. Madura tobacco productivity is determined based on TPI (Tobacco Planting Index) which is determined from the total production and leaf quality [3]. This is one thing that is important in determining prices. Determination of the price of each product to be marketed must of course pay attention to how much the costs incurred, they en ascertain what the actual price to be thrown to the market in order to get the maximum profit from the sacrifice incurred in this matter, energy and time.

The implication of marketing theory is that prices have a positive effect on demand so that prices can increase sales and income. The impact on market decision factors is that every item sold must be guaranteed to the customer in the slightest amount. This shows that the price offered must be based on the correct state of the goods offered. Nothing may happen that is covered in every product being marketed. Based on the background and previous research, this research is focused on determining the selling price of tobacco farmers. The purpose of the study can be obtained in detail how Madura tobacco farmers determine the selling price and want to know what obstacles farmers have in determining the sale price of their tobacco [4].

The urgency of this research is to obtain detailed information about the price of tobacco in farmers so that the results in this study will be a recommendation in government policy to stabilize the price of tobacco in the market. The existence of policies in favor of farmers enables the level of welfare of farmers to be better and can also improve the economy of the community, especially tobacco farmers. International Tobacco Prices, Domestic Tobacco Production Amounts, and Rupiah Exchange Rates on the value of Indonesian tobacco exports have a positive effect. International Tobacco Price Variables have a dominant influence on the value of Indonesian Tobacco Exports [5].

The results of his research are that International Tobacco Prices, Domestic Tobacco Production Amounts, and Rupiah Exchange Rates to the value of Indonesian tobacco exports have a positive effect. International Tobacco Price Variables 
have a dominant influence on the value of Indonesian Tobacco Exports [5].

\section{LITERATURE REVIEW}

The implications of marketing theory is that prices have a positive effect on demand so that prices can increase sales and incomes [4]. The impact on market decision factors is that every item sold must be guaranteed to the customer in the slightest amount. The selling price per set of sofas using the ABC method was lower than the variable method that occurred at PT Massiddo [6]. The company has not set the right and accurate selling price so that the scientific method of applying the selling price is needed in determining the selling price. The results of research on the comparison of the cost of production full costing and variable costing for the selling price of $\mathrm{CV}$. Pyramid where the results show a weakness in the calculation of the company's cost of goods because there are some things about the depreciation account of the machine and insurance is still not right [7]. Madura tobacco is a semi-aromatic tobacco so quality determines price. Madura tobacco productivity is determined based on TPI (tobacco planting index) which is determined from total production and leaf quality [8].

- Cost is interpreted as a sacrifice that can reduce cash or other assets in achieving goals, which are charged at present or in the future [9]. Costs are classified in various ways. Costs can be classified according to the object of expenditure, the main function in the company, the relationship of costs to something that is financed, its relationship with changes in the volume of activities in relation to changes in the volume of activities, the basis for the period of benefit [9].

- The cost of production consists of three cost elements, namely: direct raw materials, direct labor and factory overhead [10]. Based on the definitions above about the cost of production above can be concluded that the cost of production is the whole sacrifice in the form of costs incurred from the beginning to the end of the process and serve as a basis for determining the selling price.

- The selling price is the monetary amount charged by a business unit to the buyer or customer for the goods or services sold or delivered. Thus the selling price is determined by the seller to get profits due to the exchange of the goods [11].

- Demand and supply is the amount of goods or services requested and offered at various price levels and at a certain time with the assumption that the other components that influence are considered constant or constant. These components are income, tastes, prices, substitute goods, and others [12]. Shifting the right demand curve means an increase in demand for the goods, whereas if there is a decrease in demand there is a shift in the left demand curve [13].

- The cost of goods sold is the basic cost set (raw material costs) plus direct labor costs and plus factory overhead costs which include (supporting material costs, direct labor costs, electricity costs, building depreciation costs, costs depreciation of machinery, and other production costs), and finally the costs of freight, packaging and other sales costs [14].

\section{METHODS}

The type of this research is qualitative research. In this study there were 4 stages carried out, namely: First, observing the real conditions of tobacco farmers. Second, conducting interviews directly with tobacco farmers in Pamekasan. Third, conducting data crosschecks and analyzing by comparing theories about determining product selling prices. Fourth, recording every obstacle in the research so that it becomes a reference for subsequent research, especially in determining product selling prices.

Data analysis used is to compare theories about determining selling price and the practice of determining the selling price of tobacco to farmers. By knowing the three forms of the sale price of tobacco, this research will indirectly explore why this happens and will later become a consideration and input in government policy including farmers in work, as well as an opportunity for future research. However, the limitations of this study are only in the model of determining the selling price of slash tobacco.

\section{RESULTS AND DISCUSSION}

Geographical conditions in Madura are very suitable for growing tobacco because of the terms of soil conditions and water supply for growing tobacco. Therefore, farmers prefer to grow tobacco. In addition, the results obtained by tobacco farmers are very tempting so that the needs obtained can be used as a guarantee of daily life until the tobacco season again. Farmers also know that there is a time to grow tobacco, because tobacco plants require only a small amount of water, unlike rice and others. Farmers also know which types of soil are suitable for growing tobacco, rice, beans. Therefore, it is enough to know how to grow tobacco to produce a good harvest.

Pamekasan itself there are 3 plants that are carried out each year, namely the planting season of rice and the next 4 months of tobacco, and 4 months later to corn. Tobacco farmers' yields in Madura are very high compared to tobacco elsewhere. This is because of the aromatic tobacco and the quality of the tobacco leaves, even when the tobacco is sold at high prices.

Tobacco farmers who will be discussed in this study are farmers in the Kangenan, Pamekasan Madura location. The respondent I took was from a farmer named Mr. Muhlis, Ms. Sanah, and Mrs. Sitti and they still had a kinship and their houses were close together. He has long chosen to become a farmer, especially a tobacco farmer because of the support of his scientific knowledge about the cultivation of tobacco he has received for generations, although not all of his families' work as farmers. With this support, it is clear that he can grow crops well. According to Mrs. Sitti, saying that the yields are good 
depends on the weather, if the heat of the crop can be highly valued, whereas the weather is not supportive, it will result in a price drop and even loss. Apart from favorable weather to produce high-yielding crops are superior seeds from tobacco.

Besides the costs incurred are fertilizers, they use enough three types of fertilizers. In addition to the cost of seeds and fertilizer, they also incur labor costs and transportation costs for tobacco seedlings. In calculating the needs of the seedlings they only predict it in determining how many seedlings are there and the area of land to be planted. Planting tobacco requires a long time of about 3 to 4 months with a very long time it will require time, energy, and costs which is issued.

The process of farming tobacco plants is to plant the seedlings, watering, harvesting, then releasing the leaves from the stems and drying them for two times drying. After feeling dry and in accordance with the desired drying, they begin to collect the harvest that will be sold to Intermediaries, namely by selling only raw. Farmers sell their to Intermediaries directly by selling slash or bargaining without knowing the market price and if the price matches the desired price is immediately sold due to returning the loan money.

This could mean that the selling price method used by farmers and traders (traders) is the tebasan system. According to researchers, this is clearly very detrimental to farmers because farmers cannot provide prices according to the market. Basically there is no definite bargaining source, then there is a disadvantage whereas in the law of sale and purchase are both must be mutually beneficial i.e. the buyer gets the benefits of the goods purchased and the seller gets the profits sold from the results of his efforts.

Purchases of raw materials, seeds, fertilizers and others are not included as transportation costs or transportation costs because these costs are considered small. Whereas in this matter the fee includes the transportation fee which must be charged to the fee. In addition, even worse for labor costs they do not take into account how much labor costs to plant even though they invite people to help work on growing tobacco even though they spend so much money per person per day. When viewed, farmers do not use calculations, as long as they can sell tobacco plants above the capital they spend.

The main actor in determining the price of slash tobacco is the Intermediaries, who can bid tobacco until the deal or agreed with the price agreed in advance. And for the payment of the sale price of tobacco directly pay on the spot without any receipt or receipt of payment. This can lead to disputes which can be a problem at any time.

It turned out that after making observations and interviews in detail directly to farmers, they did not count all the costs incurred they only focus on the price offered by the Intermediaries in this case the chairman of the Kangenan, Pamekasan. Farmers only compare prices offered in accordance with the market with costs incurred. Costs incurred only on tobacco seeds, tobacco fertilizer without any other cost calculation. After they were convinced of the offer of the hobbyists and according to the farmers, they were profitable, all of the tobacco harvests were immediately handed over for sale. According to the researcher, there should be a classification of costs. So all costs incurred are recorded in accordance with the costs and benefits incurred and after being recorded and calculated can only provide prices according to the margin you want to obtain. However, it also needs to sort out the costs incurred such as the cost of raw materials including tobacco seeds, labor costs, and factory overhead costs such as fertilizer, electric water.

To determine the selling price, the seller has the price of the item to be sold, not the buyer who gives the price. This, does not side with farmers who are resigned to the price offered by the buyer. The majority of farmers in Kangenan, Pamekasan directly sell their tobacco harvests to collectors without selling their harvests processed like chopped. This is because farmers can quickly get money from selling tobacco products. So that they can pay off their debts and can fulfill their daily needs with a family for at least 1 or up to the next 3 months.

Demand and supply that occurs, Intermediaries see from the substance of tobacco, and market prices. But there are still many components that can be included in the request and offer. The most important thing is the existence of market demand which also affects the benchmark price of selling goods. The statement above reveals that the determination of the selling price of slash tobacco is only based on the current market price. So that farmers really hope that their crops do not lose and can profit according to their expectations. With this condition, the parties concerned can provide a reasonable price and help the farmers so that their crops are priced according to the efforts of the farmers who have been carrying out activities that take a considerable amount of time, energy, and material, which is not only trying only to make ends meet. In addition, technical guidance is needed in growing good tobacco by producing high quality and high-yielding crops as well as strategies to determine their crop yields so that they do not always suffer losses and, most importantly, it requires assistance and supervision to Intermediaries and supervising thugs or tobacco mafia that are very rife at the moment.

\section{CONCLUSION}

Tobacco farmers, especially tobacco farmers in Madura, do not yet have the knowledge of how to sell tobacco in order to get the maximum profit. They only think about how the crops they did before could be sold and profit. Most small farmers to start with still need a capital loan in advance or to procure goods. Though it could be that the benefits obtained by these farmers can be more than the price offered by the hobbyist. Because farmers do not take into account all the costs of growing tobacco from the initial preparation of seeds, fertilizer, to the hands of tobacco middlemen. Besides that, a regulation or price equalization is needed in the village to the city so that the farmers do not suffer losses. This will help tobacco farmers by buying their crops properly. This certainly can help improve the economy of the community. 


\section{REFERENCES}

[1] H. Sakdiyah, "Application of sales budget using the Least Square Method in estimating income in the Madura Batik Industry home," Equilibrium, vol. 1, no.1, pp. 32-44, 2013.

[2] B. Bustami and N. Nurlela, Cost of goods sold, Mitra Wancana, Yogyakarta

[3] A. Achmad , S. Sinar and S. Suwarso, "Increased Madura tobacco productivity in lowland and tegal land in Sumenep district," Embriyo, vol. 8, no. 2, pp. 108-117, 2011.

[4] T. Nicolae, A.P. Nicolae, F.S. Aurelia, "Price Determination And Price Strategy In The Marketing View, Management \& Marketing. Vol. 3, No. 4, Pp. 21-36, 2008.

[5] A.M. Kurniawati, E. Yulianto and Y. Abdillah, "The Effect of International Tobacco Prices, Domestic Production Amounts and Exchange Rates on the Value of Indonesian Tobacco Exports (Study of Indonesian Tobacco Exports in 1985-2014)," Journal of Business Administration, vol. 38, no. 2, 2016.

[6] V. Rantung, V. Ilat and H Wokas, "Analysis of selling Price Determination using variable Costing and Acticity Based Costing methods in PT. Massindo Sinar Pratama Industri," Jurnal Emba, vol. 3, no.3, pp. 1341-1348, 2015.
[7] S. Samsul and N. Hestika, "Comparative Analysis of the Full Costing Method and Variable Costing in the Calculation of Cost of Production for the Determination of Selling Prices at CV," Pyramid. Emba Journal.

[8] A. Arsyadmunir, S. Suryawati and S. Suwarso, "Increased Madura tobacco productivity in lowland and tegal land in Sumenep district," Embriyo, vol. 8, no. 2, pp. 108-117, 2011.

[9] M. Mursyidi, Cost Accounting, Conventional Costing, Just In Time dan Activity-Based Costing. Erlangga, Jakarta, 2010.

[10] A. Karjono and M. Damaiyanti, "Analisis Perhitungan Harga Pokok Produksi yang Ditetapkan oleh PT Mustika Ratu Tbk," Jurnal Institut Bisnis Nusantara: Jakarta, 2011.

[11] H. Hasen and M. Mowen, Management Accounting. Selemba Empat, Jakarta. P.40, 2009.

[12] D.A. Putra, Analysis of Factors Affecting Indonesia's Tobacco Exports to Germany. Semarang: Fakultas Ekonomi Universitas Negeri Semarang, 2013.

[13] B. Boediono, Microeconomics. BPFE, Yogyakarta P. 43, 2013.

[14] S.R. Lasena, "Analisis Penentuan Harga Pokok Produksi pada PT Dimembe Nyiur Agripro,” Jurnal, Fakultas Ekonomi, Jurusan Akuntansi Universitas Sam Ratulangi, Manado, 2013. 